\title{
Human Capital Plan for Business Startups "Innovation of Subang Honey Pineapple Beverage"
}

\author{
Dita Fryandini ${ }^{1}$, Rhian Indradewa ${ }^{2}$, Tantri YanuarRahmat $\mathrm{Syah}^{3}$, \\ Ketut Sunaryanto ${ }^{4}$ \\ ${ }^{1,2,3,4}$ Department Management, Faculty Economic and Business, Esa Unggul University, Jakarta - Indonesia.
}

Corresponding Author: Dita Fryandini

\begin{abstract}
Health is the most important capital in life choices. So that health itself is desired by everyone. Maintaining health can be done by maintaining a diet, adequate rest, exercise and consuming vitamins derived from fruits and vegetables. Increasing activity will make the body need food and drink intake that has high nutritional content. Vitamin $\mathrm{C}$ is obtained from many fruits. One of the fruits that contain lots of vitamin $\mathrm{C}$ is pineapple. Pineapple contains 3949 grams of vitamin $\mathrm{C}$ contained in half a glass (125ml) of pineapple. In addition to vitamin C, pineapple is also famous for the bromelain content in it. Pineapple is one type of fruit that is liked by the community. In Indonesia, pineapple has a high potential as an export commodity.
\end{abstract}

Keywords: Startups, Human Capital Plan, Human Capital

\section{INTRODUCTION}

PT. Limatra is a startup company that produces packaged pineapple fruit juice drinks that have advantages over similar products, as a fresh, practical and healthy packaged juice drink, so that pineapple juice can be enjoyed at any time by all people and is easy to get at any minimarket existing in Indonesia. West Java Province as one of the largest pineapple producers in Indonesia has a distribution of pineapple producers centered in Subang Regency. In 2015, Subang's pineapple production contributed $92 \%$, followed by Bogor with a contribution of $2.23 \%$. Subang pineapple is also known as honey pineapple because it has a sweet taste. In addition to its sweet taste, honey pineapple has many advantages; including honey pineapple has soft and fibrous flesh, has a high water content, and has a larger fruit size than ordinary pineapple.

\section{MATERIALS \& METHODS \\ 2.1 Human Capital Objective}

The target of Human Capital Jus Nanas (Nasnas) is made to be able to realize the goals of Human Capital. Can represent the company's strength to achieve the company's vision and mission. To achieve this goal, create a strategy for managing human resources in the company which is divided into three phases, namely shortterm, medium-term and long-term goals [1]

\subsection{Strategic 7McKinsey}

PT. Limatra in corporate strategy and analyze the success factors in this organization using McKinsey $7 \mathrm{~s}$ Framework. This tool is used to analyze the internal aspects of the company's organization using 7 main elements, namely Strategy, Systems, Skills, Style, Staff, Structure and Share-values. The McKinsey 7s Analysis Model was introduced by Tom Peters and Robert Waterman who worked as Consultants at McKinsey \& Company in the 1980s. According to them, the alignment of the seven elements in the organization is a key factor in the success of a company.[2]

\subsection{Corporate Culture}

Corporate culture is the basis of a person in the organization. Because 
corporate culture has a big influence in influencing the company's ability to change the direction of its strategy, PT. Limatra because corporate culture has a strong influence on the behavior of all employees. These values are used to measure short, medium and long term performance [3]. According to [4]The definition of corporate culture is that culture represents an unspoken code of communication among organizational members. Then PT. Limatra will always apply organizational culture.

\subsection{Structure Organization}

The organizational structure will be managed in accordance with the predetermined human capital objectives [5] Organizational structure helps employees see the division of work, as well as how different functions or activities can be well coordinated. In addition, with this structure, you can find out several specializations of a job, channel orders, and report submissions. This structure is an important component that must exist in the organization that includes the division of tasks and responsibilities of each individual, which aims to avoid overlapping individual powers and responsibilities. In addition, Human Resource Management pays attention to the development of skills, abilities, and knowledge in acquired human resources, so that the tasks and responsibilities assigned by the organization can be carried out effectively and efficiently. [1]

\subsection{Plan Human Capital}

PT Limatra's human capital planning includes estimating the number of employees, recruitment, training and development, compensation system, job evaluation, attendance, and termination of employment. Compensation is an important tool in human resources, an effective compensation system significantly influences organizational development [6] .

\section{DISCUSSION}

\subsection{Human Capital Objective}

The target of Human Capital Jus Nanas (Nasnas) is made to be able to realize the goals of Human Capital, which we can see in Table 3.1 below:

\begin{tabular}{|l|l|}
\hline Category & Human Capital Objective \\
\hline $\begin{array}{l}\text { Short-term } \\
(1-3 \text { Years })\end{array}$ & $\begin{array}{l}\text { The sales and marketing department achieved the sales target of 90\% of the set target } \\
\text { Hiring a freelancer will create 90\% product brand awareness in the Subang area and its surroundings for pineapple } \\
\text { juice products } \\
\text { Development training plans are prepared twice a year by each division }\end{array}$ \\
\hline $\begin{array}{l}\text { Medium-term } \\
\text { (3-5 Years) }\end{array}$ & $\begin{array}{l}\text { With the addition of freelance West Java expansion 90\% reached the target } \\
\text { Fulfilled the addition of product development division }\end{array}$ \\
\hline $\begin{array}{l}\text { Long-term } \\
\text { More than 5 Years }\end{array}$ & $\begin{array}{l}\text { Fulfilled employees for PT Limatra Branch in Java Island } \\
\text { Fulfillment of additional QC for Central Java and East Java }\end{array}$ \\
\hline
\end{tabular}

\subsection{Strategic 7McKinsey}

McKinsey 7s Framework can be one of the tools of choice for conducting internal analysis of a company's organization. The following are 7 elements in the McKinsey 7s Framework Strategy, Structure, System, Skill, Staff, Style, and Shared Values, which we can see in Table 3.2 below:

Table3.2 Framework Mckinsey 7S

\begin{tabular}{|l|l|}
\hline Strategy & $\begin{array}{l}\text { Provide opportunities for employees to channel creative ideas and ideas to make employees more developed, able to work } \\
\text { together and provide rewards to motivate other employees who focus on company growth by expanding the market and } \\
\text { product development. }\end{array}$ \\
\hline Structure & $\begin{array}{l}\text { PT Limatra uses a functional organizational structure. The functional organizational structure is formed based on the tasks that } \\
\text { exist in the organization. }\end{array}$ \\
\hline $\begin{array}{l}\text { Rekturment } \\
\text { Payroll using the Online Payroll system } \\
\text { Attendance (Finger Print) and Car Attendance Application } \\
\text { Workforce Management (training management, evaluation, relocation, success, and discipline) } \\
\text { Work Planning, Work Allowance } \\
\text { Environmental reporting (employee complaints such as accidents, health, work environment) } \\
\text { Company and employee data recording } \\
\text { Recording of employee job information } \\
\text { System benefit (pension fund) }\end{array}$ \\
\hline
\end{tabular}


Dita Fryandini et.al. Human capital plan for business startups "innovation of subang honey pineapple beverage".

\begin{tabular}{|l|l|}
\hline \multicolumn{2}{|c|}{ Table 3.2 Continued... } \\
\hline Skills & $\begin{array}{l}\text { Hard Skill (specific ability on job description) } \\
\text { Marketing technical skills training. } \\
\text { Ability to analyze processed materials and product results } \\
\text { Financial Analysis and Reporting Skills } \\
\text { Soft skills (personality, personal, communication skills required), Integrity, Leadership, Leadership }\end{array}$ \\
\hline Staff & $\begin{array}{l}\text { Training as needed,Giving rewards in achieving work } \\
\text { Selection process with appropriate qualifications } \\
\text { Appropriate salary, Hold regular discussions between leaders and subordinates }\end{array}$ \\
\hline Style & Democratic leadership style (ability to influence others and work together to achieve goals and objectives) \\
\hline $\begin{array}{l}\text { Share } \\
\text { Values }\end{array}$ & Striving For Excellenge, Teamwork, Inovatif, Responsibility \\
\hline
\end{tabular}

\subsection{Corporate Culture}

Corporate culture is the basis of a person in the organization. Because corporate culture has a strong influence on the behavior of all employees, it also has a major influence on the company's ability to change the direction of its strategy. Some things that are included in the corporate culture are artifacts, work uniforms, company logos, office layouts. The reference culture at PT. Fivetra that we can see in Table 3.3 below:

\section{Table 3.3Corporate Culture}

\begin{tabular}{|l|}
\hline Nasnas Culture \\
\hline Striving For Excellence \\
\hline Teamwork \\
\hline Innovative \\
\hline Responsibility \\
\hline
\end{tabular}

\subsection{Assumption}

Table3.4 Assumption SDM PT. Limatra

\begin{tabular}{|l|l|}
\hline \multicolumn{1}{|c|}{ Nilai } & \multicolumn{1}{c|}{ Assumption SDM } \\
\hline $\begin{array}{l}\text { Striving For } \\
\text { Excellence }\end{array}$ & $\begin{array}{l}\text { PT Limatra always prioritizes improving work results beyond what is expected and according to the target of each } \\
\text { employee to achieve company goals. If there is an increase in work, a reward will be given, and if there is no increase } \\
\text { in work, a small reward will be given. }\end{array}$ \\
\hline Teamwork & $\begin{array}{l}\text { PT Limatra provides special office space facilities for all employees to relax and enjoy breaks aimed at establishing } \\
\text { good relations, working together between teams to achieve company targets, if the company targets are achieved they } \\
\text { will be given rewards, and if not achieved will be given small rewards. }\end{array}$ \\
\hline Innovative & $\begin{array}{l}\text { PT Limatra always evaluates what its employees produce within a period of 3 months. Every 3 months employees are } \\
\text { required to express any ideas or innovations related to the interests of the PT Limatra company, either individually or } \\
\text { in the form of a team. If the proposal is good, it will be rewarded, and if the proposal is not good, it will be rewarded. }\end{array}$ \\
\hline Responsibility & $\begin{array}{l}\text { PT Limatra will determine if the working employee can complete his task and is fully responsible for his work seen for } \\
\text { 1 year, if it is very good it will be given a reward and if otherwise it will be given a small reward. }\end{array}$ \\
\hline
\end{tabular}

\subsection{Structure Organization}

The following is the organizational structure of PT Limatra as for the duties and responsibilities of each position below, the addition of employees is marked with the following colors:

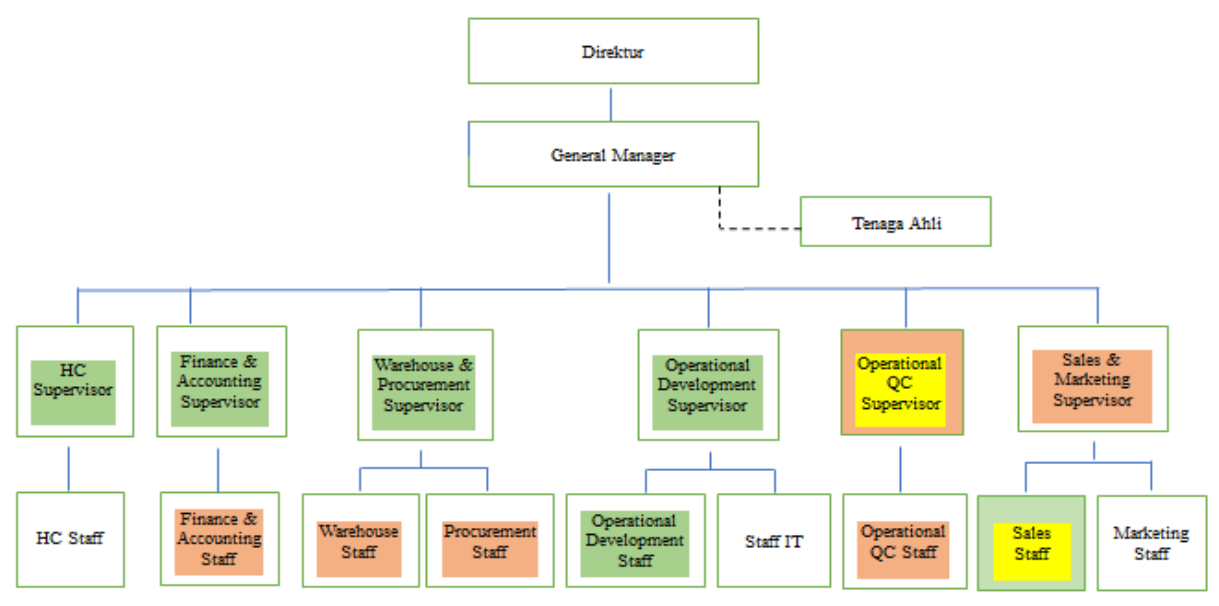

Description :

Picture3.4 Structur Organization PT Limatra

: additional employees in year additional employees in year 5 
Dita Fryandini et.al. Human capital plan for business startups "innovation of subang honey pineapple beverage".

\subsection{Human Capital Plan}

There are stages of human capital planning described as follows:

\section{a. Estimated Number of Employees}

\begin{tabular}{|l|l|l|l|l|l|} 
& 1 st & 2 st & 3 st & 4 st & 5 st \\
Total & year & year & year & year & year \\
Headcount & 18 & 21 & 28 & 30 & 41 \\
\hline
\end{tabular}

\section{b. Recruitment}

Planning the amount of Human Capital needed must be in accordance with the needs of the organization in the short, medium and long term [7] PT Limatra using the recruitment method, including the selection stage by accepting incoming application letters from candidates, after which he holds an administrative selection (checking file requirements such as ID cards, KK, SKCK, diplomas, photographs, application letters), interviews (required skills, min. level of education, work experience, min. Education D3/S1 able to complete the given job, ready to be placed in any position, able to work in a team and under pressure, able and able to solve problems quickly and accurately.

\section{c. Training and Development Strategy}

PT Limatra's stages in the training and development process include the following:

\begin{tabular}{|c|c|c|c|c|c|c|c|c|c|c|c|c|c|c|c|c|}
\hline \multirow{2}{*}{ Ne } & \multirow{2}{*}{ training type } & \multirow{2}{*}{ Trainee. } & \multirow{2}{*}{ Trainer. } & \multirow{2}{*}{$\begin{array}{l}\text { training } \\
\text { type }\end{array}$} & \multicolumn{12}{|c|}{ month } \\
\hline & & & & & 1 & 2 & 3 & 4 & 5 & 6 & 7 & 8 & 9 & 10 & 11 & 12 \\
\hline 1 & Market leader & $\begin{array}{c}\text { All } \\
\text { Employees }\end{array}$ & $\begin{array}{l}\text { Dircktur/M } \\
\text { anager/ } \\
\text { Supervisor }\end{array}$ & Internal & $\checkmark$ & & & & & & $\checkmark$ & & & & & $\sqrt{ }$ \\
\hline 2 & creative marketing & $\begin{array}{l}\text { Supervisor } \\
\text { and Staff }\end{array}$ & Manager & Internal & $\checkmark$ & $\checkmark$ & $\checkmark$ & & & & & & & & & \\
\hline 3 & Product Development & $\begin{array}{c}\text { Supervisor } \\
\text { and Staff }\end{array}$ & Manager & Internal & $\checkmark$ & $\sqrt{ }$ & $\checkmark$ & & & & & & & & & \\
\hline 4 & $\begin{array}{l}\text { Leadership dan } \\
\text { Teamwork }\end{array}$ & Supervisor & Vendor & Eksternal & & & & & & $\sqrt{ }$ & & & & & & \\
\hline 5 & Market leader & $\begin{array}{c}\text { All } \\
\text { Employees }\end{array}$ & $\begin{array}{c}\text { Direktur/M } \\
\text { anager// } \\
\text { Supervisor }\end{array}$ & Internal & & & & & & & & & & & & $\checkmark$ \\
\hline
\end{tabular}

Table3.6 Employee Development Type

\begin{tabular}{|l|l|}
\hline Jenispengembangan & Keterangan \\
\hline Competence test & Selected employees \\
\hline Career path & $\begin{array}{l}\text { Selected employees (according to } \\
\text { performance evaluation) }\end{array}$ \\
\hline Rotation Job & $\begin{array}{l}\text { Conducted in the 2nd year the company } \\
\text { was established, taking into account the } \\
\text { stability of the work unit }\end{array}$ \\
\hline
\end{tabular}

\section{d. Compensation System}

\section{- Direct Compensation}

Table 3.7 Direct Compensation
\begin{tabular}{|c|l|c|c|c|c|}
\hline \multirow{2}{*}{ No. } & \multirow{2}{*}{ Item } & \multicolumn{5}{c|}{ Position } \\
\hline & & Staff & Unit Head & Manager & Direktur \\
\hline 1 & Salary & $\sqrt{ }$ & $\sqrt{ }$ & $\sqrt{ }$ & $\sqrt{ }$ \\
\hline 2 & Positional allowance & & $\sqrt{ }$ & $\sqrt{ }$ & $\sqrt{ }$ \\
\hline 3 & Overtime & $\sqrt{ }$ & & & \\
\hline 4 & BPJS of Employment & $\sqrt{ }$ & $\sqrt{ }$ & $\sqrt{ }$ & $\sqrt{ }$ \\
\hline 5 & BPJS of Healthy & $\sqrt{ }$ & $\sqrt{ }$ & $\sqrt{ }$ & $\sqrt{ }$ \\
\hline 6 & THR & $\sqrt{ }$ & $\sqrt{ }$ & $\sqrt{ }$ & $\sqrt{ }$ \\
\hline 8 & Reward** & $\sqrt{ }$ & $\sqrt{ }$ & $\sqrt{ }$ & $\sqrt{ }$ \\
\hline
\end{tabular}

- Indirect Compensation

\begin{tabular}{|l|} 
Table 3.8 Indirect Compensation \\
\begin{tabular}{|c|c|}
\hline \multicolumn{2}{|c|}{ Calculation of BPJS by employees } \\
\hline BPJS JHT & $2,00 \%$ \\
\hline BPJS JP & $0,64 \%$ \\
\hline BPJS KS & $0,33 \%$ \\
\hline Calculation of BPJS by company \\
\hline BPJS JHT & $4,54 \%$ \\
\hline BPJS JP & $1,28 \%$ \\
\hline BPJS KS & $1,31 \%$ \\
\hline
\end{tabular}
\end{tabular}

\section{- Non Financial Compensation} a. Permanent employees

PT Limatra implements a work system in accordance with Law No. 11 of 2020 concerning job creation article 60 paragraph 1 and will only end when the employee has entered retirement, dies, or submits a resignation. give a probationary period first to new employees for 3 months, After the probationary period ends, the new employee is appointed as permanent. 
Dita Fryandini et.al. Human capital plan for business startups "innovation of subang honey pineapple beverage".

\section{b. Contract Employees}

PT Limatra establishes a contract employee system in accordance with Law No. 11 of 2020 concerning Job Creation Articles 57-59 where employees who have served an indefinite period of time. e.g. OB, Security and Driver

\subsection{Job Evaluation}

The evaluation and monitoring process is carried out in several stages, namely:

Every 6 months when a regular meeting is held, the format is in the form of a discussion

Once a year which is the final evaluation and monitoring.

Table3.9 KPI (Key Performa Indicators)
\begin{tabular}{|l|l|c|c|c|c|c|}
\hline $\begin{array}{l}\text { Name : } \\
\text { Position : } \\
\text { NIK : }\end{array}$ \\
\hline \multirow{2}{*}{ NO } & Strategic Objective & weight & target & achievement & Score & $\begin{array}{c}\text { Total } \\
\text { Score }\end{array}$ \\
\cline { 4 - 8 } & & & & & & \\
\hline 2 & Striving for Excellence & $35 \%$ & & & & \\
\hline 3 & Inovatif & $25 \%$ & & & & \\
\hline 4 & Responsibility & $20 \%$ & & & & \\
\hline
\end{tabular}

\subsection{Work Termination}

According to RUU No. 13 of 2003 was changed to the Omnibus Law Job Creation by adding 5 other important points regarding Employment, the company can lay off in various conditions the company goes bankrupt, the company closes due to loss, changes in company status, and workers commit violations.

\subsection{Financial Aspects of Human Capital}

PT. Limatra in its implementation requires costs for employees in the form of basic salary, allowances, BPJS, training and others. The total costs incurred are for employee financing as a whole. In HR planning, in 1 month PT. Limatra will recruit 18 employees. And for the 5th year the total employees reached 41 employees. PT. Limatra assumes that every employee will experience a salary increase every year for staff by $8 \%$.

\section{CONCLUSION}

As a newly established company, PT. Limatra business focus on Subang pineapple juice soft drink with a B2C business concept always trying to improve the quality of its human resources. In this case, because human resources are the most important thing in achieving the targets set by PT. Limatra. To improve competency development, always conduct training and performance development and implement corporate culture. With the existence of a clear organizational structure function, each employee gets the duties and responsibilities in accordance with the expertise that has been determined by each division of the company.

Acknowledgement: None

\section{Conflict of Interest: None}

\section{Source of Funding: None}

\section{REFERENCES}

1. L. C. Hasyim, T. Yanuar, R. Syah, R. Indradewa, and S. Pusaka. 2019. Five Success Stages in Human Capital Planning Over LH Hotel Business. Journal of Multidisciplinary Academic. 03(6). pp. 171-176.

2. R. P. Putra, T. Yanuar, R. Syah, S. Pusaka, and R. Indradewa. 2019. Human Resources Implementation Using the McKinsey 7S Method for Business Startup: Duck Nugget Frozen Food. Journal of Multidisciplinary Academic. 03(4). pp. 11-14.

3. L. Guiso, P. Sapienza, and L. Zingales. 2015. The value of corporate culture. Journal of Financial Economics. 117(1). pp. 60-76.

4. J. CRÉMER. 1993. Corporate Culture and Shared Knowledge. Industrial and Corporate Change. 2(3). pp. 351-386.

5. Saputra, R. Indradewa, T. Yanuar, R. Syah, and D. Fajarwati. 2021. Human Capital Plan for Business Startups 'Jamu Partnership' in Indonesia. International Journal of Research and Review. 8(7). pp. 370-376. 
Dita Fryandini et.al. Human capital plan for business startups "innovation of subang honey pineapple beverage".

6. H.-H. Lai. 2011. The influence of compensation system design on employee satisfaction. African Journal of Business Management, 5(26). pp. 10718-10723.

7. L. Nurlita, T. Yanuar, R. Syah, R. Indradewa, and E. Hamdi. 2021.Human Capital Implementation Strategy in the Marina Company. American International Journal of Business Management. 4(5). pp. 152-156.
How to cite this article: Fryandini D, Indradewa R, Syah TYR et.al. Human capital plan for business startups "innovation of subang honey pineapple beverage". International Journal of Research and Review. 2021; 8(10): 45-50. DOI: https://doi.org/10.52403/ijrr.20211008 